\title{
Lumen
}

Selected Proceedings from the Canadian Society for Eighteenth-Century Studies

\section{The International Impact of Lessing's Nathan the Wise}

\section{David G. John}

Volume 19, 2000

Material Productions \& Cultural Construction

Culture matérielle \& Constructions discursives

URI : https://id.erudit.org/iderudit/1012318ar

DOI : https://doi.org/10.7202/1012318ar

Aller au sommaire du numéro

Éditeur(s)

Canadian Society for Eighteenth-Century Studies / Société canadienne d'étude du dix-huitième siècle

ISSN

1209-3696 (imprimé)

1927-8284 (numérique)

Découvrir la revue

Citer cet article

John, D. G. (2000). The International Impact of Lessing's Nathan the Wise. Lumen, 19, 99-107. https://doi.org/10.7202/1012318ar

Copyright (c) Canadian Society for Eighteenth-Century Studies / Sociéte canadienne d'étude du dix-huitième siècle, 2000
Ce document est protégé par la loi sur le droit d'auteur. L'utilisation des services d'Érudit (y compris la reproduction) est assujettie à sa politique d'utilisation que vous pouvez consulter en ligne.

https://apropos.erudit.org/fr/usagers/politique-dutilisation/ 


\section{The International Impact of Lessing's Nathan the Wise}

In his recent account of Lessing's work and influence, Wolfgang Albrecht includes a section 'Zur Rezeptions- und Wirkungsgeschichte in Deutschland' ('Reception and Impact in Germany,' 163), but says nothing about the author's impact abroad. ${ }^{1}$ Despite Lessing's place in world literature, as witnessed by translations of some or all of his works into 40 languages (Seifert 254-343, Kuhles 51-60) and the continuing volume of critical studies internationally, there has been no effort to record systematically and thoroughly the reception history of any of his plays either within German-speaking countries and the German language or beyond. What we do know about both is only fragmentarily recorded. Ursula Schulz has provided detailed accounts of Lessing performances from 1748 to 1789 , listing thirteen of Nathan within and without Germany (192), several of them merely readings or excerpts. Paul Merbach has recorded Lessing performances from 1899 to 1912, Diedrich Diederichsen and Bärbel Rudin a selection of reviews from 1945 to 1979, and Bettina Dessau new stagings in the two Germanies, Austria and Switzerland from 1945 to 1978 . These studies show that in terms of production frequency Nathan trailed Lessing's other major plays by a wide margin through the Nineteenth Century and into our own, suffering from 1933 to 1945 a complete ban under National Socialism, but rose from the ashes with a host of post-war productions (Dessau lists 264 of them, 280-88). Also important for twentieth-century reception is Gerhard Stadelmaier's commentary on selected Lessing productions from 1968 to 1974, which fills many gaps in our understanding of his reception and impact, and there are other localized snapshots listed by Seifert and Kuhles as well as the annual bibliographies of Germanistik and the MLA. Albrecht calls a thorough study of Lessing reception 'ein dringendes Desiderat' ('an urgent necessity,' 105). We may recall Lessing's unpublished draft prologue to Nathan der Weise: 'Noch kenne ich keinen Ort in Deutschland, wo dieses Stück schon jetzt aufgeführt werden könnte. Aber Heil und 
Glück dem, wo es zuerst aufgeführt wird' ('I know of no place in Germany where this play could be performed at the moment. But all hail and best wishes to whatever place performs it first': Werke II, 748-49). He rightly anticipated the rocky production road of Nathan in his own time and milieu, but never dreamed of the impact it would have on far-flung shores nor the interest it would generate for centuries. I cannot fully address this weakness in Lessing scholarship now, but a start can be made by focussing on four key examples of Nathan's modern internationalization. They include Ferdinand Bruckner's New York adaptation (1942), German adaptations by Heiner Müller (1976) and George Tabori (1991), and finally a unique African production of 1993 which has gone completely unnoticed by Lessing scholarship to date.

The Viennese expressionist playwright Ferdinand Bruckner (18911958, born Theodor Tagger), emigrated to the USA in 1936, where he lived until 1951. Famous for his innovative, arresting stage effects, he wrote Die Rassen (The Races, première 1933) as an attack on racial terrorism, and in his adopted home city of New York in the early forties continued his interest in the Jewish question with an international focus through his production of Nathan on Broadway in 1942. His sponsor and ally was Erwin Piscator, the place, Piscator's studio theatre in New York's New School of Social Research. ${ }^{2}$ Against the background of a World War, deep distrust of German politics and traditions, and growing resentment toward Jewish immigrants in New York, this production was intended nevertheless to encourage the discussion and support of German-Jewish immigration. Bruckner's adaptation changed the focus of the play from world religions per se to their relationship with the modern secular state (Bayerdörfer 173). The adaptation therefore went beyond what had long been the traditional theme of Nathan as Jew and his relationship to the Christian world, transcending the religious question, and addressing broader issues of international society and politics, as Bayerdörfer explains:

In erster Linie geht es um den Nachweis der Existenz eines anderen Deutschlands, dessen Maximen und Werte, dessen Eintreten für religiöse und rassische Toleranz, wie Piscator auch ausdrücklich im Programmheft betont, den Werten der amerikanischen Verfassung näher sind als das, was sich als offizielles Deutschland des Nazismus im Feindbild präsentiert ... die Aufführung bedeutet auch den Versuch, dieses Amerika bei seiner eigenen Tradition, d.h. bei der "Declaration of Human Rights" zu behaften und zur Wachsamkeit gegen die durchaus vorhandenen, zwar nicht rassistisch begründeten, aber ökonomisch bedingten antisemitischen Erscheinungen der Gesellschaft, vor allem im Großraum New York, aufzurufen. ${ }^{3}$ 
While not a sensation, the production received a warm reception from audiences and critics, a considerable triumph considering the international, national and local animosities involved. Its success was such that it was repeated in 1944 and linked with post-performance discussions both in the theatre and extensively in journalistic and intellectual circles (Bayerdörfer 179-83), again with general praise and support. Nathan on Broadway is one of the first modern examples of how Lessing's work became a means to address problems of international society.

Perhaps his perspective from within a decaying totalitarian state or perhaps the condition of modern society as a whole pushed Heiner Müller to transform Nathan from a statement of tolerance and optimism to a hopeless expression of individual, social and ecological bankruptcy, for that is what his Lessings Schlaf Traum Schrei. Ein Greuelmärchen (Sleep Dream Scream. A Horror Fairy Tale) represents. This bitterly cynical commentary on Lessing's idealism and on North America is an extreme expression of a writer swallowed by a pit of pessimism. The play is one of a trilogy, the other two just as negative (Leben Gundlings/Gundling's Life, Friedrich von Preußen/Frederick of Prussia). ${ }^{4}$ The three comprise a statement on the bankruptcy of 'enlightened' German political, scientific and intellectual history, with Emilia Galotti and Nathan as leading examples of the artistic vacuum. As a group the trilogy recalls the tripartite winged altars that we all recognize as part of the spiritual development of the German people, and which remain as outstanding examples of their artistry and craftsmanship over centuries, from medieval iconography to Lucas Cranach's disturbing surrealistic compositions in the Sixteenth Century and the unsettling trilogies painted by Max Beckmann and Otto Dix in our own (Buck 484). Müller's play is cynically destructive. He presents Lessing to the President of the United States on a North Dakota scrapyard, the enlightenment playwright's new world stage. Here, he is hopelessly out of place, with no possibility of intelligent reception, his work grotesquely incompatible with the violent, chaotic New World, itself a symbol of a doomed modern society. In the end, like his own Spartacus, Lessing becomes an anachronistic icon of a futile struggle:

\section{Projektion}

\section{APOTHEOSE SPARTAKUS EIN FRAGMENT}

Auf der Bühne ein Sandhaufen, der einen Torso bedeckt. Bühnenarbeiter, die als Theaterbesucher kostümiert sind, schütten aus Eimern und Säcken Sand auf den Haufen, während gleichzeitig Kellner die Bühne mit Büsten von Dichtern und Denkern vollstellen. Lessing wühlt im Sand, gräbt eine Hand aus, einen Arm. Die Kellner, nun in Schutzhelmen, verpassen Lessing eine Lessingbüste, die Kopf und Schultern bedeckt. Lessing, auf den Knien, macht vergebliche Ver- 
suche, sich von der Büste zu befrein. Man hört aus der Bronze seinen dumpfen Schrei. Applaus von Kellnern Bühnenarbeitern (Theaterbesuchern). ${ }^{5}$

George Tabori's Nathan provides no relief. Alison Scott-Prelorentzos has written the best scholarly account of his 1991 staging of Nathans Tod. Nach Lessing (Nathan's Death. Adapted from Lessing), the première, offensively enough, in Wolfenbüttel. ${ }^{6}$ Scott-Prelorentzos notes that Tabori, a Hungarian Jew, was writing with an 'awareness of antagonism to asylum-seekers [in modern Germany] and growing anti-Semitism,' an atmosphere that 'hovered over the ceremony' when he was awarded the Büchner prize in 1992 (49). Tabori's championing the cause of asylumseekers recalls the collaboration between Bruckner and Piscator in New York, but while their theatre experiment led to dialogue and improved understanding, Tabori's could produce nothing but despair. The script remains unpublished, but from an archival copy Scott-Prelorentzos provides a careful comparison with Lessing's original and illuminating insights into what this production was all about. She quotes the reactions of reviewers who title their commentaries with such epithets as 'Satan der Weise' ('Satan the Wise,' Gerhard Stadelmeier, FAZ; Scott-Prelorentzos 69n22) and 'Die Macht des Bösen' ('The Power of Evil,' Vil; ScottPrelorentzos 70n27). She describes the difference between the central idea in Lessing and Tabori's versions thus: 'In Lessing the parable-scene is the centrepiece, where Saladin's intellectual curiosity about this liberal-minded Jew turns to emotional conviction and admiration: universal tolerance is the parable's hopeful prophecy for the future, but a beginning is made in the present. With Tabori the parable is not even a lament for what might have been, but truly a fairy-tale as in common parlance, something with no link to reality (58).' In Tabori, 'Violence, cynicism, illicit sexuality support the play's exposure of the bankruptcy of reason and morality (65),' which is not at all far from Heiner Müller's depiction of Lessing and his ideals fifteen years earlier. Scott-Prelorentzos concludes: '[Tabori's play] in fact narrows Lessing's scope, for it focusses attention on the Jew as a Jew. Lessing's Die Juden is about Jews and anti-Semitism ... but Nathan der Weise is not (66).' Scott-Prelorentzos' rejection of Tabori's one-sided interpretation of Nathan is entirely justified and is counterbalanced by her own insistence that the play has much more cultural range than the plight of the Jews, adding that 'a Moslem ... would have difficulty relating to this [Tabori's] piece.' Professor Scott-Prelorentzos can be heartened by our final example, which not only demonstrates the extraordinary transcultural message of Nathan, but does so in a language and at a venue unique to its reception history.

The 1993 production of Nathan in Addis Ababa, Ethiopia, was the first and to my knowledge remains the only one ever mounted on the world's 
second-largest continent. This alone makes it worthy of attention but to date it has been unnoticed by scholars. The fact that it took place in Africa's oldest standing theatre, the Hager Fiker (meaning 'patriotic'), in a country with a highly unusual, volatile religious history involving Christianity, Judaism and Islam, makes this production all the more fascinating. ${ }^{7}$ An ancient country, now a Federal Democratic Republic with a population of just under 59 Million, Ethiopia today has two major religious groups: Muslim, almost $50 \%$ of the population, and Orthodox Christian, almost $40 \%$. The remainder of the population practices for the most part tribal religions, and there are almost no Jews. ${ }^{8}$ Just eighteen years ago, in 1980, the prominence of the two major religions in Ethiopia was reversed: in 1980 Muslims represented just over 30\%, as opposed to nearly $50 \%$ today; Christians in 1982 just under $50 \%$, as opposed to under $40 \%$ now. This is an astonishing shift in statistical and demographic terms. Furthermore, twenty years ago there was also a thriving Jewish community of 16,000 in Ethiopia, who almost to a person left their homeland for Israel to escape centuries of antisemitism and persecution.

Briefly summarized, modern Ethiopian history has involved the replacement of Emperor Haile Selassie in 1974 by a socialist ruling junta, repeated violent revolts aided by the Sudan and Somalia, the seizing of power from President Mengistu by the Ethiopian People's Revolutionary Democratic Front (EPRDF) in 1991, a new constitution in 1994, and the country's first multi-party general elections in 1995. Today the political and religious situation there remains extremely volatile. It was thus a courageous act to produce Lessing's Nathan in Addis Ababa in the season of 1993/94, precisely at the time when the People's Revolutionary Democratic Front seized power amid a climate of violence and fear. In many ways the sponsors of the play, the Goethe Institute and the management of the Hager Fiker theatre, were speaking out through Nathan in a way similar to Lessing's own actions in 1778.

Not surprisingly, interest in the production was high and ticket sales brisk. ${ }^{9}$ The play was performed in the Semitic Amharic, Ethiopia's 'official' and dominant local language. The translator from English into Amharic verses was Nebiy Mekonnen, who himself had suffered a decade of imprisonment during the Mengistu regime. He also played the role of the friar. Sets and costumes were designed and constructed under the direction of Florence von Gerkan of the Thalia Theatre in Hamburg, and technical equipment arrived by generous donation from Berlin, the city of Nathan's première in 1783 . In consultation with translator and actors the German director Hellmut Reinke from Berlin made substantial cuts to Lessing's text, but politically-charged portions remained and stirred the public's deepest reactions. Debebe Eshetu, one of the most beloved of Africa's actors and president of the Union of 
African Performing Artists, who had also served a lengthy prison term during the former regime, played Nathan. The program booklet contained Nebiy Mekonnen's full Amharic text, an interview in Amharic with Teferi Alemu, the theatre's general manager, photographs of the various characters in scenes from the play, as well as other materials. ${ }^{10}$

In his notes, translator Mekonnen comments in a strikingly frank way on the importance of the translation and production generally: ${ }^{11}$

It is delicate because it deals with religion which, in Ethiopia, is almost a taboo even to discuss about: very volatile and very fragile! It .... handles the issue of tolerance pertaining to a fair and permissive attitude toward those whose race, religion, nationality, opinions and practices, etc. differ from one's own. Evidently, its criticality sharpens if the tolerance is between major religions, Christianity, Judaism and Islam in this case. Especially nowadays, in association with social, political or economic contexts, the subject of tolerance is one of the most vital elements that is lacking in Ethiopia and elsewhere in Africa. I strongly felt and ardently believed that Nathan the Wise, written about two hundred years ago, transcends centuries, for art knows no boundaries, as if to fill the gap created due to lack of tolerance in the African continent, particularly in Ethiopia (154-55).

In light of the repeated savagery in parts of Africa in recent years - not to mention examples of genocide on other continents - how can one comment further on such a statement, from such an individual, in such a time and place? Lessing could not have been more delighted with the impact of his play in a culture so very removed in language, geography, religion and values from his own. ${ }^{12}$

In conclusion, it is evident that the impact of Lessing's Nathan within his own language and German-speaking countries has been addressed only fragmentarily by scholarship. Perhaps more important is the fact that its impact internationally has been almost completely ignored as a field for systematic research, and while this essay has concentrated on Nathan, the same observation could be made about scholarship on Lessing's other major plays as well. The modern renditions I have discussed demonstrate that continuing study of Nathan raises our understanding of the play above the level of the German-Jewish question to gain timeless and international proportions. Rather than focusing on the lacuna in reception during the two centuries between Nathan's première and the 1980s, modern Lessing scholarship should turn its attention to recent performances of Lessing's text and its adaptations, especially in countries and languages different from his own. Our final example, the first Nathan on the African stage, is enough to suggest that such an 
approach will provide as yet unknown, meaningful avenues to continue our appreciation of Lessing's relevance for our age.

\author{
DAVID G. JOHN \\ University of Waterloo
}

\title{
Notes
}

1 Translations from German to English in this essay are my own.

2 Hans-Peter Bayerdörfer has written the only scholarly account I know of this production and I have relied on it for my synopsis. Bruckner's adaptation is unpublished. Bayerdörfer bases his analysis on the director's playbook (Regiebuch) located in the archive of the Erwin Piscator Center of the Academy of Fine Arts in Berlin (173 n19).

3 'It is primarily a matter of showing the existence of another Germany whose maxims and values, whose support of religious and racial tolerance, as Piscator makes explicit in the program notes, stand closer to the values of the American constitution than those presented by official Nazi Germany ... the performance is also an attempt to take America to task on the basis of its own tradition, that is, the Declaration of Human Rights, and to arouse its vigilance against evidence of antisemitism in society, especially in the greater New York area, even if it is founded in economic problems rather than racism': (Bayerdörfer 178).

4 Theo Buck's extensive article considers the entire trilogy. Joachim Fiebach's postscript to his edition of Müller's play is also instructive; see especially pp. 118 and 123 .

5 'Projection / APOTHEOSIS SPARTACUS A FRAGMENT / On stage a sand heap covering a torso. Stage hands dressed as theatre-goers empty sand from pails and sacks onto the heap while waiters fill the stage with busts of poets and thinkers. Lessing burrows in the sand, digs up a hand, an arm. The waiters, now in protective helmets, place a Lessing bust over him, covering his head and shoulders. Lessing, on his knees, makes vain attempts to free himself from the bust. His muffled cry is heard from within. Applause among waiters, stage hands (theatre-goers)':(Müller 101; see also Lessing's Spartacus fragment, Werke II, 574-77 \& 788-89; and Buck 489).

6 Beyond Scott-Prelorentzos' sources, readers might wish to consult Franz Wille's lively account of the production in Theater heute. His final words, 'Augen zu, Vorhang auf! / Eyes closed, curtain up!' (3), serve warning.

7 I have used background information on the Hager Fiker as well as theatre in Ethiopia and Africa from Martin Banham, ed., The Cambridge Guide to Theatre, pp. 325-27, The Cambridge Guide to African and Caribbean Theatre, pp. 31-36, and Joan Plastow, African Theatre and Politics. Ethiopian theatre is relatively little researched, in part because a great deal of it is in Ethiopia's official language Amharic or in the other languages of Ethiopia's seventy or so nationalities. 
8 My factual sources of general information on Ethiopia are the 1998 World Almanac, p. 763, from which I paraphrase extensively in this paragraph, and The Encyclopaedia Britannica. 1980 statistics are from the Britannica Book of the Year for 1985, p. 674.

9 Details from Inka Bach's account of the production in Theater der Zeit (Nov/Dec 1993), here p. 68.

10 I am grateful to Sabine Hagemann-Ünlüsoy, director of the Goethe Institute in Addis, for giving me a copy of the program booklet; to her predecessor Christine Meuer who led the Institute at the time the play was produced; to Elisabeth Fibich of the Goethe Institute in Munich for making the connections; and to Abza W. Gebremedhén, a graduate student in Chemistry at the University of Waterloo, whose native language is Amharic.

11 There is some awkwardness in the original English, but I have left it so since it does not disturb the meaning of what is said.

12 The play was remounted at the Hager Fiker theatre in 1997, when the political atmosphere was perhaps even more volatile.

\section{Works Cited}

Albrecht, Wolfgang. Gotthold Ephraim Lessing. Stuttgart: Metzler, 1997.

Bach, Inka. 'Ringparabel in Afrika. Lessings "Nathan der Weise” wurde am Hager Fiker Theater in Addis Abeba erstaufgeführt.' Theater der Zeit 4 (1993): 68-71.

Banham, Martin. The Cambridge Guide to Theatre. Cambridge: UP, 1992.

Banham, Martin, Erroll Hill and George Woodyard, eds., Olu Obafemi advisory ed. for Africa. The Cambridge Guide to African and Caribbean Theatre. Cambridge: UP, 1994.

Bayerdörfer, Hans-Peter. 'Nathan am Broadway. Ferdinand Bruckners Lessing-Inszenierung - Gastgeschenk eines deutschen Juden an ein Immigrationsland.' Itta Shedletzky and Hans Otto Horch, eds. Deutsch- jüdische Exil- und Emigrationsliteratur im 20. Jahrhundert. Tübingen: Niemeyer, 1993. Pp. 165-83.

Britannica Book of the Year. Chicago: Encyclopaedia Britannica, 1985.

Buck, Theo. 'Zwei Träume vom deutschen Theater. Anmerkungen zu Heiner Müllers Lessing-Tryptichon.' Georg Stötzel, ed. Germanistik: Forschungsstand und Perspektiven. Vorträge des Deutschen Germanistentages 1984. Berlin: de Gruyter, 1985. Pp. 478-91.

Dessau. Bettina. Nathans Rückkehr. Studien zur Rezeptionsgeschichte seit 1945. Frankfurt/M.: Lang, 1986.

Diederichsen, Diedrich and Bärbel Rudin, eds. Lessing im Spiegel der Theaterkritik 19451979. Berlin: Gesellschaft für Theatergeschichte, 1980.

Encyclopaedia Britannica, The New. Macropaedia. Knowledge in Depth. 15th ed. Vol. 22. Chicago: Encyclopaedia Britannica, 1985.

Kuhles, Doris. Lessing-Bibliographie 1971-1985. Berlin: Aufbau, 1988.

Lessing, Gotthold Ephraim. Werke. Ed. Herbert G. Göpfert. 8 vols. München: Hanser, 1970. 
Nathan der Weise [in Amharic translation.] Translated by Nebiy Mekonnen, with photographs and materials appended in Amharic and English. Addis Ababa: Goethe Institute, [1993].

M[erbach], P[aul] A[lfred]. 'Lessing-Aufführungen an deutschen Bühnen 1899 bis 1912 [statistical table].' Lessing-Buch. Berlin: Mittler, 1926. P.66.

Müller, Heiner. Lessings Schlaf Traum Schrei. In Die Schlacht/Traktor. Leben Gundlings. Friedrich von Preußen. Lessings Schlaf Traum Schrei. Mit einem Nachwort von Joachim Fiebach. Berlin: Henschel, 1977.

Plastow, Joan. African Theatre and Politics: the Evolution of Theatre in Ethiopia, Tanzania and Zimbabwe. Amsterdam: Rodopi, 1996.

Schulz, Ursula. Lessing auf der Bühne. Chronik der Theateraufführungen 1748- 1789. Bremen: Jacobi, 1977.

Scott-Prelorentzos, Alison. "Plus c'est la même chose, plus ça change!' George Tabori's Nathans Tod. Nach Lessing.' Ed. Marianne Henn and Christoph Lorey. Analogon Rationis. Festschrift für Gerwin Marahrens zum 65. Geburtstag. Edmonton: no pub., 1994. Pp. 49-71.

Seifert, Siegfried. Lessing-Bibliographie. Berlin: Aufbau, 1973.

Stadelmaier, Gerhard. Lessing auf der Bühne. Ein Klassiker im Theateralltag (1968-1974). Tübingen: Niemeyer, 1980.

Wille, Franz. 'Nathans Not. George Taboris Lessing-Variation, uraufgeführt in Wolfenbüttel.' Theater heute 12 (1991): 2-5.

World Almanach and Book of Facts 1998, The. Mahwah NJ: K-III Reference Corp., 1997. 